\title{
Beneficial Images: Batik handicraft tourism in Yogyakarta, Indonesia
}

\author{
Hengky, S. H. \\ Director, SHINE Institute, Associate Professor \\ Triguna, School of Economics, Department of Business Management, Indonesia \\ Tel: 62-896-5704-5738Ｅ-mail: hengky_halim@yahoo.com.au
}

Received: November 17, 2014 Accepted: December 4, 2014

doi: 10.5296/ber.v5i1.6760ＵRL: http://dx.doi.org/10.5296/ber.v5i1.6760

\begin{abstract}
The purpose of this study was to respond Philologist arts practitioner's statements, by exploring the performance of beneficial images of batik handicraft tourism in Yogyakarta. This one year's quantitative research was conducted from July 2013 - July 2014 in Yogyakarta. The data were collected randomly, stratified sampling, triangulation, and based on the content analysis, by distributing 300 questionnaires to 100 respondents. This study found that batik handicraft tourism performance has beneficial image strength for tourists. It's indicated that most of the tourists consider going to Yogyakarta because of the beneficial impact of the City of the World Batik of Yogyakarta. Every part of the experience of tourists became very important and be a part of beneficial image attributes: a sense of place, infrastructure, culture, types and standards of service, and impressions. The main beneficial image of tourists about the batik handicraft tourism: Social tourism become the first point which attracting the tourists; the Uniqueness of batik handicraft, which expressing a philosophy and interpretation; the Conditional; and the Emotional influence their decision.
\end{abstract}

Keywords: Beneficial Images, Beneficial Impacts, Social Tourism, Conditional, Emotional

\section{Introduction}

Along with the anniversary of the 50th year, the World Crafts Council (WCC) states Yogyakarta as the City of the World Batik. This Council is to focus on the craft. The memorial was held on 18 to 23 October 2014 located in Dongyang, Zhejiang Province, China (Prasetyo, 2014; and Widyatmoko, 2014).

Speaking further about the city of Batik World of Yogyakarta, the city is well known as the city of the student, is indeed a very worthy, and respected with the title "City of the World Batik". Traditionally, the city is considering with stronger philosophy. The palace of Yogyakarta is 
well known by the world through this predicate. Most of tourists, who shall visited Yogyakarta want to know about the unique and famous city. Recently, Yogyakarta already crowded by the tourists and as the city of the world batik craft, this city visited by a lot of local and foreign tourists.

So many potential tourism attractions in Yogyakarta where completed the choice for tourists as well. Not many regions in Indonesia, which has a wealth of local attractions such as truly special region of Yogyakarta from the natural beauty of the beach, batik handicraft, inheritance, and the Malioboro. One of the famous attractions is the batik handicraft tourism (Sha, 2012).

Batik handicraft tourism is a masterpiece traditional of the Indonesia, which become an integral part of Yogyakarta, and also been able to provide economic benefits to the local community of Yogyakarta. In addition, it had high artistic and historical values.

Philologist arts practitioners of the Gajah Mada University, said that the public and the government of the Yogyakarta did not need to be euphoric with the label of the City of the World Batik. Hence, for the next step needed more in-depth study of the craft of batik (Mahmud, 2014)

Yogyakarta has gained the title of "City of the World Batik", and Philologist arts practitioner of the Gajah Mada University mentioned that it needed more study of the batik handicraft. Therefore, the purpose of this study is to respond to the statement of the Philologist arts practitioner, by exploring the performance of the beneficial images of batik handicraft tourism in Yogyakarta.

\section{Literature Review}

Beneficial Images are a framework of the destination image of tourists, who decided to visit destinations within or outside their state for the purpose of travelling or vacation. Beneficial Image conceptualized as a characteristic that greatly affects the image of the tourist on making their decision for a travelling or holiday for the certain destination. While, Echtner \& Ritchie (1993) found tourists' beneficial images of a batik handicraft tourism destination consisted of a number of components-based images attribute: impressions holistic, functional characteristics, psychological, unique, and common.

The image and tourist destination of the batik handicraft tourism consists of a mixture of the positive and negative images. If there are two destinations are equally attractive to tourists, they will avoid going to the tourism destination which has a negative image. Tourists decide to travel to the tourism destination which has a favorable image (Tapachai and Waryszak, 2000). The beneficial attributes of batik handicraft tourism perceived by tourists are fair price, exotic batik, friendly community, historic places, and experience a unique culture.

The batik handicraft tourism is a part of tourism destination where tourists can find peace and relaxing place. In terms of tourism handicraft of batik, beneficial image in the mind of tourists: Exotic batik; Friendly community, Historic places where produces the unique and original batik, and Experience a unique culture. The attribute of beneficial images of batik handicraft tourism visualized as the concept of the five value dimensions (Tapachai \& Waryszak, 2000): 
Functional; Social; Emotional; Epistemic; and Conditional.

Functional Suitability (Sirgy \& Su, 2000) is the match between the attributes and ideal expectations and the benefits of the destination. Meanwhile, Phau, Vanessa, \& Shanka (2014) states that the value and functional conditions in the tourism destination: The quality of infrastructure; and Private insurance benefits from tourists.

Social tourism is all tourists' activities which undertaken by tourists who have a chance to go on their vacation, regardless of the economic and social situation (Haukeland, 1990). Meanwhile, Minnaert (2007) found that social tourism is a form of tourism that related to the economic development and the evolution of civilization in the destination. Social tourism plays a very important role in the development of tourism access.

The association of tourism industry has partnerships with public authorities and the private sectors, trade unions, businesses, and all segments of the population to get the benefit from the batik handicraft tourism. In addition, McCabe, Minnaert, \& Diekmann (2012) defining batik handicraft tourism as a social activity of tourists in facilitating their vacation with unlimited access in their free time and interacting with the local community. This participation rate is highly dependent on the performance of the economic development and the quality of the social tourism.

Emotional (Tuckera, 2009) and affective dimensions greatly affect the flow of tourist discourse, including an equitable relationship between tourists, tour operators and the public. While tourist satisfaction was mediated by their interaction: Emotional experience of tourists: Intentions; and Behaviors. Emotional (Prayaga, Hosanyb, \& Odehc, 2013), was shown as a state of joy, love, positive surprises, comfort and discomfort.

Service satisfaction was experienced by tourists, has a significant correlation between the orientation of tourists' personality, and their emotional (Gountas \& Gountas, 2007). There are three main factors that significantly affect the emotional state (Brunner-Sperdin, Peters \& Strobl, 2012) of tourists, namely: recreational experience, hardware and human ware.

Tourism is the activity of social, cultural, and emotional or resource mobility (Maximiliano, Korstanje, \& Mustellier, 2014) and a method to understand the social behavior of the tourists. The Batik handcraft tourism is tourism activities in recreation and enjoys the beauty of batik handicraft with social and cultural activities. On the other hand, if social, cultural, and emotional activities not so well, the batik handicraft tourism would appear as an isolated activity that makes a great psychological distance between the tourists as a guest, and the local community as the host.

Conditional causality (Katircioglua, Feriduna, \& Kilinc, 2014) indicated where tourist spending their money as a catalyst for energy consumption and it increases the level of carbon dioxide emissions. Conditional factors (Abbruzzoa \& Bridab, 2014) determined by spending money of tourists on their travelling in the socio-demographic activities, buying the batik handicraft as they like, and the duration of their plan to spend time at the destinations.

The perception of tourists is a very important to the batik handicraft destination as the image in 
the form of an overview of products, which made by artisans the batik handicraft product associative. The perception of the batik handicraft tourism is about the destination image which formed by the perception of the tourists.

Beneficial images of international and national tourists to the City of World Batik as a batik handicraft tourism. The tourists decided to travel to Yogyakarta because they feel the batik's handicraft tourism was made in the City of World Batik and it's equipped with hospitality of the community and easy to get a batik handicraft that is significantly important when they think of Yogyakarta as a tourism destination the batik handicraft (Henkela, Henkela, Agrusaa, Agrusaa, \& Tannera, 2006).

As aforementioned that the characteristics of beneficial images (Tapachai \& Waryszak, 2000) for each attribute of the batik handicraft tourism: Functional (Sirgy \& Su, 2000) is the quality of infrastructure, and private insurance benefits from tourists; Social tourism (Haukeland, 1990; Minnaert, 2007; and McCabe et al, 2012) is all tourist activities undertaken by tourists who have a chance to go on their vacation with unlimited access in their free time and interaction with the local community. Moreover, Emotionally (Brunner-Sperdin et al, 2012 and Prayaga et al, 2013) was shown by recreational experience and human-ware, as a joyous feeling, positive surprises, and comfortable; Epistemically (Hall, 2010) as economic, institutional and political barriers; and Conditionally, where tourists spending their money, buying the batik handicraft, and spending the leisure time at the destinations (Katircioglua et al, 2014; and Abbruzzoa \& Bridab, 2014).

\section{Methodology}

This one year's quantitative research was conducted from July 2013 - July 2014 in Yogyakarta. The data were collected randomly, stratified sampling, triangulation, and based on the content analysis, by distributing 300 questionnaires to 100 respondents: Tourists; The batik handicraft's merchants and batik handicraft industry; The Governor staffs; Taxi drivers; Bus drivers; Travel agencies; Front offices' officers; Merchants of local food; and Local community. Each respondent was questioned three different times for the consistency of their response (Jenning, 2001).

The collected data was tabulated by the content analysis (Gottschalk, 2013; and Cohen, 1960), which focus on beneficial images (Tapachai \& Waryszak, 2000): Functional (Sirgy \& Su, 2000); Social tourism (Haukeland, 1990; Minnaert, 2007; and McCabe et al, 2012); Emotional (Brunner-Sperdin et al, 2012 and Prayaga et al, 2013); Epistemic community (Hall, 2010); and Conditional of tourists (Katircioglua et al, 2014; and Abbruzzoa \& Bridab, 2014).

The content analysis of the beneficial images (Gottschalk, 2013; and Cohen, 1960): Exploratory analysis of beneficial images; Posting each attribute of beneficial images; Frequency of beneficial images; Frequency counted of beneficial images; and Discussions.

\section{Results and Discussions}

Based on the beneficial images (Tapachai \& Waryszak, 2000), the tabulation (Table 1) of content analysis (Gottschalk, 2013; and Cohen, 1960), indicates that performance of batik 
handicraft tourism has a beneficial image for tourists $(K=0.640)$. The indication, they consider going to travel to Yogyakarta as the City of the World Batik. Tourists find batik handicraft tourism as a friendly social tourism and Yogyakarta is a nice place to spend with good accessibility. They feel friendly response from the local community (Nip-Nip, 2014).

Social tourism in Yogyakarta is the most significant attributes of the beneficial images of the tourists' image. It reflects that tourist activities are the main point of beneficial images as a friendly social life, interact and dealing with the batik handicraft seller or cuisine's merchants, and socializing with the local community.

Table 1. Tabulation of Beneficial Images of Batik Handicraft in Yogyakarta

\begin{tabular}{|l|c|c|}
\hline Beneficial Images: Batik Handicraft tourism in Yogyakarta & Value & $\%$ Freq \\
\hline Functionality, quality-infrastructure-private insurance benefits & 37 & 0.1927 \\
\hline Social tourism, tourist activities-vacation-free time-local community & 42 & 0.2188 \\
\hline Emotional, recreational experience -human ware & 38 & 0.1979 \\
\hline Epistemically, economic - institutional - political & 36 & 0.1875 \\
\hline Conditional of tourists, spending money-accommodation-spend time & 39 & 0.2031 \\
\hline Kappa Coefficient $=\mathrm{K}=0.640$ & & \\
\hline
\end{tabular}

The interaction between the tourists and the traders became important information and it affects the character, color direction, and composition of the manufacture of batik handicraft motifs in the future (Fitinline, 2013). The creation of a variety of decorative motifs of batik handicraft is based on that information and more emphasis on simplicity of expression to meet the needs of the community clothing. Simplicity was contained in a form inspired by the natural environment and daily events.

The character of the direction of the color and composition of a batik handicraft motif containing various values of wisdom, whether express or implied, in the manufacture of motifs, uses, and the philosophy of the batik handicraft. The batik experts in making batik handicraft, started from sheets of white cloth so that it becomes patterned and useful for us as clothing or as a textbook of social institutions (Fitinline 2013).

In terms of batik handicraft interpretation (Soegenkity, 2013), the motif is derived from the word "Batu" and "Barong" (lion). "Batu" means a pattern, while "Barong" means something big, and this is reflected in the large size of the pattern on the fabric. Motif Parang Barong is the mother of all motives machete. This motif has a meaning that a king always careful and can control themselves.

Parang motif of batik handicraft is very well used by the knights, and it's symbolized of the efforts to defend the country from the enemy threats. Only, batik handicraft with the motif of "Parang" abstinence when worn by the bride's wedding procession. Local people claimed that the bride will always live in the dispute. Parang is derived from the word "Batu". The patterned of batik handicraft "Parang" including a decorative, its meaning that only the king and his relatives were permitted to wear. The size of the motif of batik handicraft's "Parang" is also symbolized the wearer's social status within the kingdom. The direction of batik handicraft "Parang" motif used by women in Yogyakarta is from top left to bottom right. As for the men, 
"Parang" motif direction from upper right to lower left (Syukur, 2012).

The motif Kusumo Parang of batik handicraft means that life should be guided by the struggle to find a fragrance outwardly and inwardly, which is like a flower fragrance. Thus, for the Javanese people, who living in most major communities, sought the wisdom of life is personal fragrance without leaving the prevailing norms and manners in order to avoid disaster and unseen (Soegenkity, 2013).

Thereby, the craft of a batik cloth-write (Kardinata, 2009) not merely a cloth, but it became an art form which made with a creativity (Abad21, 2013), taste and intention maker. Decorative motifs are usually affected and closely related to the following factors: (1) Geographic location; (2) Beliefs and customs; (3) the State of the surrounding nature, including flora and fauna; (4) Any contact or relationship between the regions producing batik handicraft; and (5) the Nature and procedures of the relevant local livelihoods.

Conditionally (Katircioglua et al, 2014; and Abbruzzoa \& Bridab, 2014), tourists who visit Yogyakarta can find a market which offering wide range of the batik handicraft at Beringharjo. Most of the batik handicraft has been made in a form of clothes, gloves, children's clothing, women's clothing, or are still in the form of cloth. They choose the batik handicraft which matched with their wants and dealing the price with the batik craft seller. Other than that, they interacted with cuisine's merchants, socializing with local communities, spending a leisure time in several green hotels, having an entertainment in some luxurious hotel, or visit the shop at the Malioboro Street, where the local community sold the handicraft.

The Malioboro Street is one of the famous shopping tourism in Yogyakarta that the tourists can get the batik handicraft. They can buy a variety of handicrafts and souvenirs from accessories desired beautiful, unique souvenirs, classical batik craft, gold and gems for household appliances. There are a variety of locally made souvenirs such as batik handicraft, rattan ornament, silver, bamboo crafts, puppets, Blangkon, miniature traditional vehicles, accessories, and the key chains (Pratama, 2014; and Utomo, 2014).

Closed to the Malioboro Street, there is the Beringharjo market. Most of the tourists like to spend their leisure time and buying several kinds of the batik handicrafts around Yogyakarta. All shopping-tourism destinations around Yogyakarta become social-cultural interaction between tourists and the seller of the batik handicraft. It's become social attractiveness to tourists, and once lucrative traditional batik handicraft artisans, travel agents, hotels, restaurants, cafes, and local communities.

The Beringharjo is a traditional market in Yogyakarta, which also become an attractive shopping destination for tourists. They can buy a wide variety of batik craft with a friendly price, of course with good quality batik craft. Many tourists come to the market to buy the art and culture of Yogyakarta. The data released from the Tourism Office of Special Region of Yogyakarta shows the number of tourists in 2012 reached 1,881,911, an increase of approximately 5\% over the previous year (Pertiwi, 2013).

Anyhow, the Batik handicraft industry grows significantly, it's indicated by the economic contribution of batik craft USD 240.1 million in 2006, and in 2010 increased to USD 323.1 
million. Meanwhile, the value of batik craft exports in 2006 was US \$ 14.3 million and in 2010, reaching US \$22.3 million, or an increase of 56\%. The amount of labor absorbed by the batik craft industry reached 916,783 people in 2010 , and the number of consumers who buy batik craft recorded 72.86 million people (Berita, 2014).

The emotional connection between the tourists and the local community is not only based on financial gain and social interaction, but rather in the process of socio-cultural interaction and adaptation which is a shared responsibility of the stakeholders and shareholders in Yogyakarta. Social integration between the tourists and the local community can be realized jointly by them at the time of recreation like the impression of joy, positive surprises, and comfort or discomfort.

A sense of place, infrastructure, culture, interpretation, types and standards of service, and impressions, influence the emotional connection between tourists and the seller of the batik handicraft. The emotional and affective dimensions greatly affect the flow of tourist discourse, including a more equitable relationship between tourists, the seller of the batik handicraft, and the local community.

Moreover, the emotional of the tourists to have the batik craft also influence by their images of Yogyakarta as the City of World Batik. They are proud of wearing the batik craft which they buy from the City of the World Batik, as well as they like to know more about the culture of the city. It makes them, impress to get the batik craft, which match with their taste and interest. The design, color, fabrics, and the story behind them would strengthen their impression as well.

While tourist satisfaction was mediated by the interaction: Emotional experience of tourists: Intentions; and Behavior. Emotional (Prayaga, Hosanyb, \& Odehc, 2013) is shown as a state of joy, love, positive surprises, comfort and discomfort. The basis of Tourists' behaviors: Mental states, including belief in the quality of batik; and the Desire and intend to have. Mechanism intention of the tourists describes the behavior of the individual is seen as an actor, who has a desire to have a way to buy it in accordance with their convictions (Azizah, 2014).

The theme of an advertisement and promotion are expected to be matched with the target and segment of the strategy of tourism marketing of batik craft. Emotionally and rationally, it would develop a beneficial image to the tourists, and would reach the target market of batik handicraft tourism as well. The jingle of advertising used words which can be touched emotionally and would be a beneficial image to the tourists, and be a beneficial impact to batik craft craftsmen in Yogyakarta (Widowati, 2010).

In terms of functionality, the batik craft is one of the natural of handicraft tourism attractions that are able to support Yogyakarta as the City, of the World Batik. Various sources of potential uplift the image of the city of Yogyakarta, and one of which is a craft center, with a variety of crafts that exist in the city of Yogyakarta (Wulandari, 2014).

Various batik handicrafts and the craft items grow exponentially in the city of Yogyakarta, which they produce not only sold for domestic, but they also sell them for international tourists. The production process of the batik handicraft was supported by traditional supply chain management from the stakeholders with many sources of raw materials and skills possessed 
both large and small scale artisans. They are trying to offer the best products to the tourists. Moreover, there are various kinds of batik handicrafts in the city of Yogyakarta. Some of them focused on the clothing design, and develops Yogyakarta batik craft motif with geometric and symmetric characteristics (Graphica, 2012).

In the catalogue which published by the Project Yogyakarta of Batik's handicraft described the typical Small and Medium Industry Development of Special Province of Yogyakarta. It mentioned that there are more than 400 batik handicraft motifs of both classical and modern motifs. Some of them were named and decorated the batik craft's motifs includes: the Parang; the Banji; the Herbs spread; the Water plants: the Flowers; the Animals; the Sido Asih; the Keong Renteng; the Sido Mukti; the Sido Luhur; and the "Semen Mentul" (Banguntapan, 2008).

The motifs are from the first until now passed down through the generations, so that the pattern does not change, because it makes the pattern motif, it is only done by certain people, and not every batik handicraft can create their own motives. Craftsmen of batik handicraft, just do it according to a predetermined pattern. Thus, the craft of batik is a job that is collective. For the record, the batik craft in Yogyakarta particularly and in generally performed by women, both young and old. Batik crafting expertise is generally passed down from generation to generation (Giriloyo, 2014).

Each motif, direction, and the color of batik handicraft in Yogyakarta reflect the meaning set forth by the batik handicraft artisans to meet the taste and needs of tourists. By the fulfillment of their needs, it would leave deep impression and meaning and it can stimulate the motivation of the tourists to revisit to Yogyakarta. The philosophical meaning of batik handicraft is made in Giriloyo (Kardinata, 2009) among others as the "Sido Asih". It implies the wearer when the householder's life is always full of compassion. The Sido Mukti meaning used by the bride and her life will always be in the adequacy and happiness. The Sido Mulyo implies the wearer's life will always be glorious. The "Sido Sublime" implies the wearer will be the rank of which virtuous character of good and noble. The "Wahyu Truntum", the expression of the budding romances.

Moreover, the Grompol means together or united. It implies that everything can be collected such good fortune, happiness, descendant, harmonious family life. The Fill implies adding anything less. If the fabric with patchwork motif is used to cover the sick person, they will healthy. It is according to the assumption that the sick person must be something less. The "Ratu Ruth" and "Cement Rome" symbolizes as the loyal wife. The "Mdau Bronto" symbolizes as a romance sweet or honey. The "Semen Gendhang" implies the expectation that the bride which wore the cloth quickly got a baby.

Now, batik handicraft has become a part of traditional Indonesian clothing. It is also a superior product in the country that has led Indonesia to the international market. It can be seen from the establishment of overall engineering, technology, and development-related motives and culture. It has been stated by UNESCO that Batik's craft in Indonesia has been designated as a Cultural Heritage of Humanity's Oral and non-material since October 2, 2009 (Giriloyo, 2014). 
The determination of UNESCO is certainly very supportive of the development of the batik craft industry in Indonesia, both domestically and overseas. In addition, there are also other factors that make Indonesian Batik's craft industry continues to grow, and it has its own the distinctiveness, including in primary human needs. This distinctiveness lies in the use of batik motifs. The motif shows the origins of batik handicraft was produced and reflected in the local culture.

The type and style of traditional batik handicraft relatively same, but the pattern and variations in accordance with the philosophy and culture of each region that are very diverse. Indonesia's cultural are so rich with the nation has spawned a variety of styles and types of batik handicraft tradition with their own characteristic. Batik handicraft as a clothing material becomes a basic human need throughout the world. Coupled with the human tendency has always looked beautiful. In terms of fashion and fashion, it is a reasonable if the current typical Indonesian batik handicraft becomes an icon that is able to break the world market.

Officially, since batik handicraft becomes a world heritage by the UN agency for education, science and culture (UNESCO) in 2009, national batik handicraft turnover has increased significantly. It reaches $300 \%$ or exceeded USD 83.33 million. It happened because Yogyakarta has had the beneficial impact of the enactment of Yogyakarta became the City of the World Batik (Sahana, 2014; and Widyatmoko, 2014).

The procedure adopted for recognition was done according to the 2003 UNESCO Convention on Cultural Heritage (Yashinta, 2013). The UNESCO Convention has been ratified by the government through the Government Regulation No. 78 of 2007 on January 15, 2008, Indonesia officially became a State Party to the Convention. Thus, Indonesia is entitled to nominate cultural currency to be included in the list of UNESCO representative.

Act. No. 19 of 2002 on Copyright guarantees the protection of intellectual property rights communal and personal. The area was given a freedom to register in order to be protected as the cultural wealth of the nation. It had been made by the Government of the Special Region of Yogyakarta. In this Act, the copyright is defined as the exclusive rights to the creator or the right to publish or reproduce the creation or giving permission for it not to reduce the restrictions according to the legislation in force (Article 1, paragraph 1).

The Indonesian Industry Minister also predicted the value of batik craft production in 2011 would reach growth approximately $20 \%$. Batik craft sales will continue to increase as more and more people of Indonesia using batik craft clothes in their daily lives.

Now, fabrics of batik handicraft are not only used for the dress, but it's also used for a variety of household, interior, fashion, craft and product material need everyday clothes, and even also been used in the shoe industry. Each region has its own peculiarities' character and become a style of the batik's handicraft industry. Batik craft is no longer a commodity, but it has been used the brand, which being seriously developed. As a consequence, Indonesian batik handicraft is not only being sought in the domestic market, but few of the fashion designers also have managed to penetrate international markets.

The Batik craft industry has also been spread in almost all parts of Indonesia, and its presence 
in the center of cities and rural industry, which absorb the large enough workforce. The main area of batik craft industry spreads in various provinces, such as Central Java, Yogyakarta, West Java, East Java, Jakarta, Bali, Bengkulu and Jambi. In 2008, the value of exports even reaches US \$ 32.28 million, and in the first three months of 2009 reaches US \$ 10.86 million.

\section{Conclusions}

This study found that tourism performance of batik handicraft tourism has beneficial image strength for tourists. It's indicated that they consider going to travel to Yogyakarta as the "City of the World Batik".

Every part of the experience of the tourists became very important, and be a part of the attributes of the beneficial image: a Sense of place, infrastructure; Culture; Types and standards of service; and Impressions.

However, the main beneficial image of tourists about the batik handicraft tourism: Social tourism become the first point which attracting the tourists; the Uniqueness of batik handicraft, which expressing a philosophy and interpretation; the Conditional; and the Emotional influence their decision.

The limitation of this study is time and financial support. Therefore, further study still would be conducted in several domains and aspects of batik handicraft tourism in Yogyakarta.

\section{Implication}

As aforementioned, batik handicraft tourism contributed to the Batik handicraft industry. It grows significantly $34.57 \%$ within four years, or $8.64 \%$ per year. Meanwhile, the value of a batik craft exports increase to $56 \%$ within four years, or $14 \%$ per year. In 2010, Batik handicraft industry absorbed a labor 916,783 people, and the number of consumers who buy batik recorded 72.86 million people, or equals to $28 \%$ of the community in Indonesia.

It implies the target market and economic growth still open widely. It would be increased in the future for enhancing labor market and to strengthen the infrastructure, and community empowerment would improve the batik handicraft industry. At the same time, it would strengthen cultural and heritage tourism, and job opportunity as well.

Currently, batik handicraft tourism already supporting batik craft industry and it also has been recognized internationally. It's become valuable information to the craftsmen and batik craft industry. They would create and innovate it without leave a typical of the batik handicraft. It implies that batik handicraft needs coaching, mentoring and training, especially for the SMEs by the National Crafts Council in the area of Yogyakarta.

\section{References}

Abad21, F. (2013). Batik Industries, Creative Industry Towards Indonesia, Competitive Advantage. Retrieved from https://www.academia.edu/6969133/Keunggulan_Bersaing.

Abbruzzoa, A., \& Bridab, J. G. (2014). Determinants of individual tourist expenditure as a network: Empirical findings from Uruguay, Tourism Management, 43, 36-45. http://dx.doi.org/10.1016/j.tourman.2014.01.014 
Azizah, R. M. (2014). The role of batik group "Sustainable Blessings" for women's empowerment, Undergraduate thesis, Faculty of social sciences and humanities, University Sunan Kalijaga Yogyakarta, 18-19. Retrieved from http://digilib.uin-suka.ac.id/12498/1/BAB\%20I,\%20V,\%20DAFTAR\%20PUSTAKA.pdf

Banguntapan (2008). Batik motifs Decorations Giriloyo, Tourism Bantul district. Retrieved from

http://pariwisata-kabupaten-bantul.blogspot.com/2008/11/pantai-parangtritis-komplek.html

Berita, D. (2014). Batik as a Motor Drive Economy, Directorate General of Domestic Trade. Retrieved from http://ditjenpdn.kemendag.go.id/WEB/index.php/public/information/articles-detail/berita/38

Brunner-Sperdin, A., Peters, M., \& Strobl, A. (2012). It is all about the emotional state: Managing tourists' experiences, International Journal of Hospitality Management, 31(1), 23-30. http://dx.doi.org/10.1016/j.ijhm.2011.03.004

Cohen, J. (1960). A Coefficient of Agreement for Nominal Scales. Educational and Psychological, 20, 37-46. http://dx.doi.org/10.1177/001316446002000104

Echtner, M. C., \& Ritchie, J. R. B. (1993). The Measurement of Destination Image: An Empirical Assessment, Journal of Travel Research, 31(4), 3-13. http://dx.doi.org/10.1177/004728759303100402

Fitinline (2013). Batik Ciamis, GPS Wisata Indonesia. Retrieved from http://gpswisataindonesia.blogspot.com/2013/11/batik-ciamis.html

Gottschalk, L. A. (2013). Content Analysis of Verbal Behavior: New Findings and Clinical Applications, Routledge, 19-22

Giriloyo, B. (2014). Proposed Yogyakarta Batik City Becoming the World, Center of Batik Giriloyo. Retrieved from http://batikwarisanbudaya.blogspot.com/2014/08/yogyakarta-diusulkan-menjadi-kota-batik.ht $\mathrm{ml}$

Graphica (2012). Kayu Batik Yogyakarta, Artikel. Retrieved from http://graphica.mywapblog.com/kayu-batik-yogyakarta.xhtml

Gountas, J. \& Gountas, S. (2007). Personality orientations, emotional states, Journal of Business Research, 60(1), 72-75. http://dx.doi.org/10.1016/j.jbusres.2006.08.007

Hall, C. M. (2010). Changing paradigms and global change: from sustainable to steady-state tourism, Tourism Recreation Research, 35(2), 131-143. Retrieved from http://www.cabdirect.org/abstracts/20103281110.html

Haukeland, J. (1990). Non-travelers. The flip side of motivation. Annals of Tourism Research, 17, 172-184. http://dx.doi.org/10.1016/0160-7383(90)90082-3

Henkela, R., Henkela, P., Agrusaa, W., Agrusaa, W., \& Tannera, J. (2006). Thailand as a tourist destination: Perceptions of international visitors and Thai residents, Asia Pacific Journal of Tourism Research, 11(3), 269-287. http://dx.doi.org/10.1080/10941660600753299 
Jenning, G. (2001). Tourism Research, John Willey \& Sons Australia, Ltd., 136-152.

Kardinata, H. (2009). Timeline Batik Indonesia, Design Grafis Indonesia. Retrieved from http://dgi-indonesia.com/garis-waktu-batik-indonesia/\#comment-14453

Katircioglua, S. T., Feriduna, M., \& Kilinc, C. (2014). Estimating tourism-induced energy consumption and $\mathrm{CO} 2$ emissions: The case of Cyprus, Renewable and Sustainable Energy Reviews, 29, 634-640. http://dx.doi.org/10.1016/j.rser.2013.09.004

Mahmud, F. (2014). Achieves World Batik City, Yogya must have a study about batik, Liputan6.com. Retrieved from http://lifestyle.liputan6.com/read/2122848/raih-kota-batik-dunia-yogya-harus-punya-studi-ten tang-batik

Maximiliano, E., Korstanje, M. E., \& Mustellier, L. C. (2014). Philosophical texts on travels: chronicles and testimonies of travelers, Journal of Tourism Management Research, 1(3), 60-74. Retrieved from http://pakinsight.com/?ic=journal\&journal=31

McCabe, S., Minnaert, L., \& Diekmann, A. (2012). Social tourism in Europe: Theory and Practice, British Library Cataloguing in Publication Data, 1-27.

Minnaert, L., Maitland, R., \& Miller, G., (2009), Tourism and social policy-The value of social tourism, Annals of Tourism Research, 36(2), 316-334. http://dx.doi.org/10.1016/j.annals.2009.01.002

Nip-Nip, O. (2014). Do Not Search Investment \& Business Opportunities in Jogja Before Read This Article, dokterbisnis.net. Retrieved from http://www.dokterbisnis.net/2014/04/03/jangan-cari-investasi-peluang-usaha-di-jogja-sebelu m-baca-artikel-ini/

Pertiwi, N. L. M. (2013). Tigerair Mandala Open Yogyakarta These Palembang, Kompas-Travel. Retrieved from http://travel.kompas.com/read/2013/09/06/1608270/Tigerair. Mandala.Segera.Buka.Rute.Yogyakarta-Palembang

Phau, I., Vanessa, Q., \& Shanka, T. (2014). Examining a consumption values theory approach of young tourists toward destination choice intentions, International Journal of Culture, $\begin{array}{llll}\text { Tourism } \quad \text { Hospitality } \quad \text { Research, } & \text { 125-139. }\end{array}$ http://dx.doi.org/10.1108/IJCTHR-12-2012-0090

Prasetyo, H. (2014). Make the World Craft Council Yogyakarta as the World Batik City, Tribunenews.com. Retrieved from http://www.tribunnews.com/regional/2014/10/23/ world-craft-council-jadikan-yogyakarta-sebagai-kota-batik-dunia

Pratama H. (2014). Malioboro, the World Tour. Retrieved from http://tourdunia.blogspot.com/2014/06/tempat-wisata-di-jogja.html

Prayaga, G., Hosanyb, S., \& Odehc, K. (2013). The role of tourists' emotional experiences and satisfaction in understanding behavioral intentions, Journal of Destination Marketing \& Management, 2(2), 118-127. http://dx.doi.org/10.1016/j.jdmm.2013.05.001

Sahana, M. (2014). Prerequisite World Batik Yogyakarta City, RRI.co.id. Retrieved from 
http://rri.co.id/yogyakarta/post/berita/98904/industri/prasyarat_yogyakarta_kota_kerajinan_b atik_dunia.html

Soegenkity (2013). Story Behind the Batik Motif, Beranda. Retrieved from http://morokabeh.blogspot.com/search/label/Batik

Sha (2012). Objek Wisata Yogyakarta Layak Jadi Pilihan, Liputan6. Retrieved from http://news.liputan6.com/read/383582/objek-wisata-yogyakarta-layak-jadi-pilihan

Sirgy, M. J., \& Su, C. (2000). Destination Image, Self-Congruity, and Travel Behavior: Toward an Integrative Model, Journal of Travel Research, 38(4), 340-352. http://dx.doi.org/10.1177/004728750003800402

Syukur, A. (2012). Outside profitable and build, Batik Sekar Kedhaton. Retrieved from http://batiksekarkedhaton.blogspot.com/2012_06_01_archive.html

Tapachai, N., \& Waryszak, R. (2000). An Examination of the Role of Beneficial Image in Tourist Destination Selection, Journal of Travel Research, 39(1), 37-44. http://dx.doi.org/10.1177/004728750003900105

Tuckera, H. (2009). Recognizing Emotion and its Postcolonial Potentialities: Discomfort and Shame in a Tourism Encounter in Turkey, Tourism Geographies: An International Journal of Tourism Space, Place and Environment, 11(4), 444-461. http://dx.doi.org/10.1080/14616680903262612

Utomo, Y. W. (2014). Angkringan Lik Man, Enjoy a Night in Yogyakarta with Kopi Joss, YogYES. Retrieved from http://www.yogyes.com/id/yogyakarta-culinary/angkringan-lik-man/

Widyatmoko, T (2014). Yogya officially crowned City World Batik, Merdeka.com. Retrieved from http://www.merdeka.com/peristiwa/yogya-resmi-dinobatkan-kota-batik-dunia.html

Widowati, E. (2010). As a Visual Communication Design, Promotion Facility Widya Batik Kusuma In the regency, Bachelor Thesis, Faculty of Literature and Arts, University of March, 17-23. Retrieved from http://eprints.uns.ac.id/3380/1/165740109201002431.pdf

Wulandari, D. (2014). Competition Notices Batik Nusantara, Yogyakarta State University. Retrieved from http://negeri23.rssing.com/chan-6162371/all_p54.html

Yashinta, H. (2013). National Batik Day As Opportunity For Sme Batik Producers, Welcome. Retrieved from http://yasintahening.wordpress.com/page/2/

\section{Copyright Disclaimer}

Copyright for this article is retained by the author(s), with first publication rights granted to the journal.

This is an open-access article distributed under the terms and conditions of the Creative Commons Attribution license (http://creativecommons.org/licenses/by/3.0/). 